\title{
Analisis Tiger Parenting bagi Perkembangan Emosional Anak
}

\author{
${ }^{1}$ Umi Salma Fauziyah, ${ }^{2}$ Maemonah \\ ${ }^{12}$ PGMI UIN Sunan Kalijaga \\ *e-mail:19204080005@ student.uin-suka.ac.id, \\ monah030973@gmail.com
}

\begin{abstract}
The purpose of this study was to determine the impact of applying tiger parenting style for children's emotional development. This research is a type of library research whose main source comes from research related to this research, both from scientific work, research results, books, and additional data sources derived from observations. The parenting style analyzed is the tiger parenting style. From the parenting style analyzed, the results show that emotional development in particular has more negative effects than positive effects such as children being unhappy, rarely having fun, sad because they are constantly being pressured, felling lacking authority in their own lives because everything continues to be directed by parents, until the worst is the symptoms of depression.
\end{abstract}

Keywords: Tiger parenting, emotional development

\section{INTRODUCTION}

Ahli-ahli perkembangan anak sepakat bahwa kecerdasan emosional memiliki peran penting bagi perkembangan kepribadian yang juga punya bagian dalam menentukan kesuksesan seseorang di masa mendatang. American Journal of Public Health menjelaskan bahwa anak yang memiliki kecerdasan emosional sejak kecil dapat lebih berhasil di masa depannya. Sebuah penelitian menunjukkan bahwa anak yang memiliki EQ tinggi dapat lebih bekerjasama dan mematuhi arahan. Ini menjadi salah satu alasan mereka di kemudian hari bisa mendapatkan gelar sarjana dan memulai pekerjaan sebelum usia 25 tahun.

Selain itu anak yang memiliki kemampuan EQ lebih tinggi memiliki resiko lebih kecil mengalami depresi dan kecemasan. Mereka terbiasa mengatur emosi yang ada pada dirinya dan hubungan dengan lingkungan tempat tinggalnya. Seseorang yang memiliki EQ tinggi dapat mengatur hubungan personal maupun profesional. Meski begitu bukan berarti IQ bisa dikesampingkan, karena EQ dan IQ akan lebih optimal jika berkembang secara beriringan agar anak bisa mendapat kesuksesan dengan perasaan bahagia di hidupnya.

Berdasarkan penjelasan di atas mengenai pentingnya kecerdasan emosional maka penting juga untuk terus memperhatikan perkembangan emosional dari anak itu sendiri. Sebagimana kecerdasan intelegent, kecerdasan emosional tidak dapat serta merta berkembang tanpa pelatihan atau pembiasaan sebelumnya. Maka orang-orang yang berada di sekeliling anak memiliki peran yang cukup penting berkaitan dengan perkembangan anak, sedikit banyak keluraga khususnya orang tua akan memberi pengaruh kepada perkembangan emosional anakya.

Interaksi paling intens yang dilakukan oleh anak dalam kesehariannya adalah dengan orangtua, selain itu kita juga mengetahui bahwa orangtua menjadi salah satu tumpuan anak setidaknya untuk anak yang masih berada di tingkat sekolah dasar. Alasan inilah yang membuat orangtua menjadi salah satu tokoh yang memiliki peran penting berkaitan dengan perkembangan emosional anak,. Hal ini juga 
menjadikan orangtua memiliki tanggungjawab besar bagi perkembangan anak termasuk di dalamnya perkembangan emosional.

$$
\text { Perhatian orangtua terhadap }
$$

perkembangan emosional anak salah satunya tercermin dari gaya pengasuhan yang diterapkan. Gaya pengasuhan orangtua yang diterapkan pada setiap tahapan usia akan terus mempengaruhi perkembangan anak tidak terkecuali perkembangan emosionalnya. Kecerdasan emosional seseorang saat usia dewasa bisa saja berasal dari gaya pengasuhan yang diterapkan orangtuanya. Maka orang tua perlu menerapkan gaya pengasuhan yang tepat sehingga bisa membuat perkembangan emosional anak menjadi optimal.

Secara umum ada tiga jenis gaya pengasuhan yang sering diterapkan dalam keluarga yaitu 1) gaya pengasuhan otoriter yang cenderung mengatur anak, keras dan tidak membiarkan anak mengungkapkan keinginannya, 2) gaya pengasuhan demokratis yang memberi kesempatan anak untuk mengungkapkan pendapatnya, cenderung mengajak anak berkomunikasi mengenai batasan-batasan dalam kehidupannya. 3) gaya pengasuhan permisif cenderung melepaskan anak sesuai keinginannya sendiri, tidak ada batasan jelas bagi anak dalam menjalani kehidupan.

Meski begitu ada gaya pengasuhan lain diluar tiga gaya pengasuhan yang diungkapkan oleh Baumrind, yaitu dari Amy Chua seorang professor hukum dari Yale University yang membuat memoir mengenai gaya pengasuhannya yang disebut sebagai tiger parenting, gaya pengasuhan tersebut dituangkan dalam buku yang berjudul battle hymn of the tiger mother. tiger parenting digambarkan sebagai penggabungan gaya pengasuhan otoriter dan otoritatif klasik karena mendapat skor tinggi pada dimensi pengasuhan positif dan negatif. tiger parenting telah (Kim, Wang, Shen, \& Hou, 2013).

Adanya gaya pengasuhan yang diterapkan oleh Amy Chua kepada anakanaknya ini menjadikan dasar peneliti untuk melakukan kajian mengenai bagimana dampak gaya pengasuhan tiger parenting bagi perkembangan emosional anak. Lebih lanjut, tujuan dari penelitian ini adalah untuk megetahui bagimana dampak yang ditimbulkan dari gaya pengasuhan tiger parenting bagi perkembangan emosional anak.

\section{FINDING AND DISCUSSIONS}

\section{Pengertian Keluarga}

Makna keluarga berasal dari kata yang yang diungkapkan oleh Ki Hadjar Dewantara. Kata keluarga berasal dari dua kata bahasa Jawa yaitu kawula dan warga. Dalam bahasa Jawa kuno, kata kawula diartikan sebagai hamba dan warga diartikan sebagai anggota. Jika dua kata ini diartikn secar bebas maka kaluarga dapat dimaknai sebagai anggota hamba atau warga saya. Dari sini bisa dipahami bahwa anggota dari kawula merupakan sebuah kesatun yang utuh dan saling terkait (Ahmadi \& Uhbiyati, 2001).

Keluarga merupakan kumpulan individu yang merupakan bagian terkecil di masyarakat yang terikat karena perkawinan (Keluarga merupakan kumpulan individu yang merupakan bagian terkecil di masyarakat yang terikat karena perkawinan). Latipun menjelaskan bahwa keluarga merupakan bagian lingkungan sosial yang terbentuk karena ada yang menetap, berinteraksi dalam pembentukan pemikiran, kebudayaan, serta menjadi perantara antara anak dan lingkungan. Lebih jauh Latipun mengungkapkan bahwa keluarga yang lengkap dan fungsional mampu meningkatkan kesehatan mental dan stabilitas emosional dari anggota keluarganya (Latipun, 2005).

Lestari berpendapat bahwa keluarga adalah sebuah rumah tanggga yang terdapat ikatan darah atau perkawinan atau menyediakan adanya fungsi-fungsi utama mendasar dan fungsi-fungsi ekspresif keluarga bagi para anggotanya yang memiliki keterkaitan (Lestari, 2012). Coleman dan Cressey menambahkan bahwa keluarga merupakan kelompok orang yang terhubung karena alasan pernikahan, keturunan, atau adopsi yang kemudian hidup bersamaan dalam suatu rumah tangga (Muadz \& Dkk, 2010).

Menurut Ilsan, keluarga merupakan lembaga pendidikan pertama dan yang utama dalam masyarakat, karena keluarga menjadi tempat seseorang dilahirkan dan berkembang menjadi dewasa. Perlu diketahui juga bahwa 
bentuk dan cara yang diterapka dalam pendidikan di keluarga dapat memberikan pengaruh pada pertumbuhan dan perkembangan seorang anak (Shaleh, 2016).

Dalam keluarga, ada dua tokoh yang dapat memberi pengaruh pada perkembangan anak yaitu Ibu dan Ayah. Menurut Freud seorang Ibu memberikan pengaruh lebih pada anak berkaitan dengan pembentukan pribadi dan sikap-sikap sosialnya di kemudian hari (Dagun, 2002).

Sedangkan di sisi Ayah, muncul hasil penelitian dari beberapa ahli psikologi yang menunjukkan bahwa anak yang kurang mendapat perhatian dan asuhan dari ayahnya maka perkembangannya menjadi kurang seimbang, seperti kemampuan akademis yang turun, terhambatnya aktifitas sosial, dan terhambatnya interaksi sosial. Jika ini terjdi pada anak laki-laki maka ciri kelelakiannya bisa jadi kabur. Selain itu seorang Ayah dapat memberikan bimbingan mengenai aktifitas anak, misalnya memberi kesdaran pada anak bagaimana cara menghadapi lingkungan dan situasi di luar rumah, atau mengajak anak berdiskusi dan mengenal lebih banyak hal, halhal ini menjadi cara seorang Ayah untuk mengenalkan anak pada lingkungannya yang kemudian dapat membantu perkembangannya di kemudian hari (Dagun, 2002).

Berdasarkan konsep yang telah dikemukakan di atas dapat disimpulkan bahwa keluarga merupakan kumpulan orang yang tinggal dalam suatu rumah, karena dasar ikatan pernikahan yng sah dan mereka saling berhubungan sert terus berinteraksi dalam menjalin keharmonisan rumah tangga.

\section{Gaya Pengasuhan}

Baumrind mengungkapkan bahwa yang dimaknai dengan gaya pengasuhan yaitu serangkaian sikap yang dimunculkan oleh orang tua kepada anaknya untuk membangun suasana emosi yang didalamnya terdapat interaksi orangtua dengan anak. (Lestari, 2012).

Berdasarkan uraian yang ada maka dapat diketahui bahwa gaya pengasuhan merupakan serangkaian sikap yang ditampakkan oleh orangtua saat berinteraksi dengan anak, yang diterapkan semasa pertumbuhan anak dan dapat memberikan pengaruh atau efek pada perkembangannya.

\section{Perkembangan Emosional Anak Usia Sekolah Dasar}

\section{Pengertian Perkembangan Emosional}

Perkembangan (development) adalah bertambahnya kemampuan (skill) dalam struktur dan fungsi tubuh yang lebih kompleks dalam pola yang teratur dan dapat diramalkan, sebagai hasil dari proses pematangan. Disini menyangkut adanya proses diferensiasi dari sel-sel tubuh, jaringan tubuh, organ-organ dan sistem organ yang berkembang sedemikian rupa sehingga masing-masing dapat memenuhi fungsinya. Termasuk juga perkembangan emosi, intelektual, dan tingkah laku sebagai hasil interaksi dengan lingkungannya (Soetjiningsih, 1995).

Perkembangan dapat diartikan sebagai "perubahan yang progresif dan kontinyu (berkesinambungan) dalam diri individu dari mulai lahir sampai mati". Pengertian lain dari perkembangan adalah perubahanperubahan yang dialami individu atau organisme menuju tingkat kedewasaannya atau kematangannya (maturtion) yang berlangsung secara sistematis, progresif, dan berkesinambungan, baik menyamgkut fisik (jasmaniah) maupun psikis (rohaniah) (Yusuf, 2008).

Santrock menjelaskan bahwa perkembangan merupakan pertumbuhan yang terjadi terus menerus dan sifatnya tetap. Ini menjelaskan bahwa yang perkembangan seseorang terjadi secara dinamis, perkembangan selalu mengalami perubahanperubahan yang sifatnya progresif dan saling berkaitan (Desmita, 2005).

Dalam pembahasan psikologi, perkembangan dapat dipahami sebagai proses perubahan kuantitatif dan kualitatif seseorang dalam masa hidupnya, mulai dari dalam kandungan, bayi, kanak-kanak, remaja, sampai dewasa. Dalam kamus psikologi Chaplin menjelaskan bahwa perkembangan adalah perubahan yang terjadi pada organisme sejak lahir sampai mati, adanya pertumbuhan dan perubahan integrasi jasmani ke dalam fungsional dan munculnya kedewassaan (Latifa, 2017). 
Emosi merupakan suatu dorogan untuk melakukan sesuatu, kecenderungan untuk melakukan sesuatu ini dibentuk oleh pengalaman kehidupan serta budaya. Emosi juga dimaknai sebagai rasa yang timbul seperti gembira, marah, kecewa, cinta, dan semangat. Seutan yang diberikan pada psuatu perasaan dapat mempengaruhi cara seseorang berpikir tentang perasaan tersebut, dan bagaimana ia bertindak (Setyowati, 2013).

Emosi adalah perasaan yang muncul dari diri seseorang, bisa bersifat positif atau negatif. Sedangkan dalam pengertian sederhana emosi dipahami sebagai kondisi kejiwaan manusia (Mulyani, 2013). Menurut Retno, emosi adalah perasaan intens yang ditujukan kepada seseorang atau suatu kejadian. Berkaitan dengan faktor yang mempengaruhi perkembangan emosi peserta didik, sejumlah penelitian tentang emosi anak menunjukkan bahwa perkembangan emosi mereka bergantung pada faktor kematangan dan faktor belajar. reaksi emosional terkadang belum muncul pada awal masa kehidupan tapi bukan berarti tidak ada, reaksi tersebut mungkin saja muncul seiring berfungsinya system endokrin.

Umar Fakhrudin menjelaskan bahwa perkembangan emosi merupakan proses yang berjalan secara perlahan dimana anak dapat mengatur dirinya ketika menemukan rasa nyaman, atau bisa dibilang anak mempelajari emosinya secara bertahap (Mulyani, 2013). Untuk mencapai kematangan emosi, anak perlu mempelajari situasi yang dapat menstimulus munculnya reaksi emosional. Salah satu cara yang dapat dilakukan yaitu membahas masalah pribadinya dengan orang lain (Latifa, 2017).

\section{Fase Perkembangan Emosi Anak Pada Usia Sekolah Dasar}

Fase perkembangan emosi anak pada usia sekolah dasar; 1) Pada usia 5-6 anak mulai mempelajari kaidah dan aturan yang berlaku. Anak mempelajari konsep keadilan dan rahasia. Anak mulai mampu menjaga rahasia. Ini adalah keterampilan yang menuntut kemampuan untuk menyembunyikan informasi-informasi secara baik. 2) Anak usia 7-8 tahun perkembangan emosi pada masa ini anak telah menginternalisasikan rasa malu dan bangga. Anak dapat memverbalisasikan konflik emosi yang dialaminya. Semakin bertambah usia anak, anak semakin menyadari perasaan diri dan orang lain. 3) Anak usia 9-10 tahun anak dapat mengatur ekspresi emosi dalam situasi sosial dan dapat berespon terhadap distress emosional yang terjadi pada orang lain. Selain itu dapat mengontrol emosi negative seperti takut dan sedih. Anak belajar apa yang membuat dirinya sedih, marah atau takut sehingga belajar beradaptasi agar emosi tersebut dapat dikontrol. 4) Pada masa usia 1112 tahun, pengertian anak tentang baik-buruk, tentang norma-norma aturan serta nilai-nilai yang berlaku di lingkungannya menjadi bertambah dan juga lebih fleksibel, tidak sekaku saat di usia kanak-kanak awal. Mereka mulai memahami bahwa penilaian baik-buruk atau aturan-aturan dapat diubah tergantung dari keadaan atau situasi munculnya perilaku tersebut. Nuansa emosi mereka juga makin beragam (Suriadi \& Yuliani, 2006).

\section{Faktor yang Dapat Mempengaruhi Perkembangan Emosi Anak}

Terdapat beberapa faktor yang dapat mempengaruhi perkembangan emosi anak, yaitu: 1) Keadaan individu; Keadaan individu pada anak, misalnya cacat tubuh ataupun kekurangan pada diri anak akan sangat mempengaruhi perkembangan emosional, bahkan akan berdampak lebih jauh pada kepribadian anak. Misalnya rendah diri, mudah tersinggung, atau menarik diri dari lingkungannya. 2) Lingkungan keluarga; Salah satu fungsi keluarga adalah sosialisasi nilai keluarga mengenai bagaimana anak bersikap dan berperilaku. Keluarga adalah lembaga yang pertamakali mengajarkan individu mengeksplorasi emosinya. Keluarga merupakan lingkungan pertama dan utama bagi perkembangan anak. Keluarga sangat berfungsi dalam menanamkan dasar-dasar pengalaman emosi, karena disanalah pengalaman pertama didapatkan oleh anak. Keluarga merupakan lembaga pertumbuhan dan belajar awal yang dapat mengantarkan anak menuju pertumbuhan dan belajar selanjutnya.

Pola asuh yang diterapkan keluarga terhadap anak juga memberi dampak yang besar bagi perkembangan emosinya, dan pola asuh yang diterapkan bisa sangat beragam. Ada yang bersifat otoriter, memenjakan anak, 
acuh tak acuh, tetapi ada juga yang penuh cinta kasih. Perbedaan pola asuh seperti ini dapat berpengaruh terhadap perbedaan perkembagan emosi (Yusuf, 2008). 3) Interaksi dengan teman sebaya. Anak seringkali membangun interaksi dengan teman sebayanya secara khas dengan cara berkumpul untuk melakukan aktifitas bersama. Interaksi antara individu ini biasanya bersifat intens serta memiliki kohesivitas dan solidaritas yang tinggi. Tujuan positif dari interaksi ini untk memenuhi minat mereka bersama. 4) Interaksi dengan sekolah; Para guru merupakan tokoh yang sangat penting dalam kehidupan anak, selain menjadi tokoh intelektual guru juga menjadi tokoh otoritas bagi mereka. Oleh karena itu, tidak jarang anak lebih percaya, lebih patuh, bahkan lebih takut kepada guru daripada kepada orangtua. Posisi guru semacam ini sangat strategis apabila digunakan untuk pengembangan emosi anak melalui penyampaian materi-materi yang positif dan konstruktif (Ali \& Asrori, 2006).

\section{Ekspresi Emosi Anak}

Emosi yang umum pada anak usia sekolah dasar adalah rasa takut, khawatir/cemas, marah, cemburu, merasa bersalah dan sedih, ingin tahu, senang, dan cinta/kasih saying. 1) Rasa takut; Takut adalah jenis emosi anak yang berkaitan erat dengan upaya pertahanan diri terhadap bahaya. Rasa takut juga bisa ditimbulkan oleh ingatan tentang pengalaman yang tidak menyenangkan. Ekspresi emosi anak yaitu panik, lari, menghindar, menutup muka, bersembunyi, dan menangis. 2) Rasa malu; Rasa malu merupaka bentuk ketakutan yang ditandai oleh penarikan diri dari hubungan dengan orang lain yang tidak dikenal atau tidak sering berjumpa. 3) Rasa canggung; Canggung adalah reaksi takut terhadap manusia, bukan pada obyek atau situasi. Rasa canngung merupakan keadaan khawatir yang menyangkut kesadaran-diri. 4) Rasa khawatir; Khawatir biasanya dijelaskan sebagai khayalan ketakutan atau gelisah tanpa alasan. Tidak seperti ketakutan yang nyata, rasa khawatir tidak langsung ditimbulkan oleh rangsangan dalam lingkungan tetapi merupakan produk pikiran anak itu sendiri. Rasa kahawatir timbul karena membayangkan situasi berbahaya yang mungkin akan meningkat. Kekhawatiran adalah norma pada masa kanak-kanak, bahkan pada anak-anak yang penyesuaiannya paling baik sekalipun.

5) Rasa cemas; Cemas adalah keadaan mental yang tidak enak berkenaan dengan sakit yang mengancam atau yang dibayangkan. Rasa cemas ditandai oleh kekhawatiran, ketidaknyamanan, dan rasa tidak baik yang tidak dapat dihindari seseorang. 6) Rasa marah; Marah adalah jenis emosi anak yang disebabkan oleh terhambatnya keinginan. Ekspresi emosi anak yaitu menangis, berteriak, memukul, membanting barang, dan bergulingguling di lantai. 7) Rasa cemburu; Cemburu adalah jenis emosi anak karena adanya rasa tidak nyaman dengan kehadiran seseorang yang dianggap sebagai kompetitor. Biasanya terjadi pada kelahiran adik di tengah keluarga. Anak merasa adanya pengalihan perhatian dari orang tua dan orang-orang dewasa di sekitarnya. Ekspresi emosi anak yaitu usil, tidak menyukai bahkan melukai adiknya. 8) Rasa sedih; Sedih adalah jenis emosi anak atas kehilangan sesuatu yang dianggap penting dan dicintainya. Bisa karena berpisah dengan teman bermain atau kehilangan binatang kesayangannya. Ekspresi emosi anak yaitu menangis, berwajah murung, mengambek atau tidak mau makan. 9) Rasa senang; Senang adalah jenis emosi anak sebagai bentuk ungkapan perasaan terhadap situasi atau sesuatu yang sesuai dengan harapan. Ekspresi emosi anak bermacam-macam yaitu tepuk tangan, tertawa, tersenyum, melompat-lompat kegirangan, mencium benda atau orang yang disayanginya (Yusuf, 2008).

\section{Pengasuhan Tiger Parenting}

Tiger parenting digambarkan sebagai penggabungan gaya pengasuhan otoriter dan otoritatif klasik karena mendapat skor tinggi pada dimensi pengasuhan positif dan negatif. tiger parenting telah (Kim et al., 2013). Bagaimanapun, penelitian berdasarkan pada orangtua Cina-Amerika, menunjukkan gaya pengasuhan ini mungkin saja sudah berakulturasi. (Xie \& Li, 2019). Beberapa penelitian telah menemukan bahwa orang tua Cina lebih otoriter dan kurang otoritatif daripada orang tua Barat, dan beberapa telah mengakui bahwa konseptualisasi Barat tentang 
gaya pengasuhan anak mungkin tidak sesuai secara budaya (Xie \& Li, 2019).

Studi empiris telah menemukan bahwa konseptualisasi Barat mengenai dimensi dan profil parenting tidak sesuai secara budaya untuk orang tua Cina sebagimana diketahui bahwa gaya pengasuhan orang tua di Cina tidak dapat diklasifikasikan ke dalam tiga tipologi, dan dengan demikian merekomendasikan beberapa dimensi dalam setiap gaya pengasuhan dalam studi hubungan orang tua dan anak (Xie \& Li, 2019). Konseptualisasi gaya pengasuhan orang Barat mungkin tidak cukup peka secara budaya untuk menangkap karakteristik pengasuhan orang Cina-Amerika (Minkyeong \& Joel, 2013).

Chao (1994) mengusulkan bahwa kontrol orang tua untuk ibu-ibu Cina-Amerika melibatkan jia`o xun (yaitu, melatih atau mendidik anak untuk menunjukkan perilaku yang sesuai), sebuah konsep yang tidak termasuk dalam praktik pengasuhan orang Barat. Chao lebih lanjut berpendapat bahwa pola asuh Tionghoa Amerika termasuk konsep adat gua $n$, yang memiliki konotasi positif karena dapat berarti "memerintah" serta "mencintai atau merawat." (Minkyeong \& Joel, 2013).

Konfusianisme dan Taoisme adalah inti dari budaya dan sistem nilai Cina yang memandu interaksi perilaku dan sosial. Secara umum, kedua doktrin ini menganjurkan penolakan terhadap individualitas dan penegasan diri dan menjaga keseimbangan antara entitas alami, manusia, dan spiritual. Oleh karena itu, salah satu keharusan mendasar dari budaya Tiongkok adalah untuk menjaga hubungan dan saling ketergantungan di antara individu.

Pengasuhan Cina adalah kombinasi dari

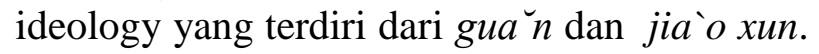

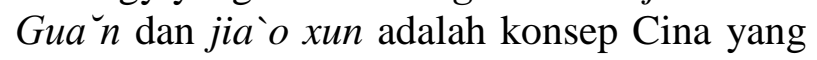
mencontohkan tugas pengasuhan menurut

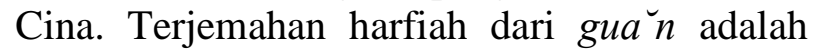
"untuk memerintah" atau "untuk mengendalikan", dan terjemahan literal dari jia `o xun adalah "untuk menegur" atau "untuk menghukum". Namun, terjemahan literal sering menyebabkan kesalahan penerjemahan atau salah tafsir. Terjemahan semantik mungkin lebih baik untuk memahami konsep aslinya.

Dari pendekatan terjemahan semantik, gua $n$ dapat ditafsirkan sebagai "untuk menjaga atau mengatur" sementara jia`o xun dapat diartikan sebagai "untuk mengajar atau melatih" dan "untuk disiplin". Secara literal terjemahannya menyampaikan kekerasan yang dingin, sedangkan terjemahan semantik menyampaikan tugas pengasuhan orang tua Cina dan menuntut keunggulan dari anak-anak. Gua $几$ mewakili bagian penting dari keyakinan pengasuhan anak yang dianggap unik untuk budaya Cina (Liew, 2010).

Jadi, ketika para anak Cina-Amerika dalam sampel menjalani pelatihan pengasuhan anak, mereka mungkin merasakan konotasi positif di balik pengasuhan anak (misalnya, orang tua mengambil tanggung jawab mereka untuk mendisiplinkan mereka), sehingga pengasuhan anak ini memiliki implikasi positif untuk keterlibatan sekolah mereka (Chang \& Qin, 2017).

Istilah tiger mom, diciptakan oleh Amy Chua untuk merujuk pada seorang ibu yang keras dan menuntut dengan harapan tinggi untuk keberhasilan akademik anak-anaknya (Xie \& Li, 2019). Chua menyajikan gaya pengasuhan tiger parenting sebagai gaya yang ganas dalam mendisiplinkan anak-anak dan menempatkan nilai tinggi pada keunggulan akademik termasuk kewajiban pada keluarga, selaian itu juga menuntut kepatuhan. Seorang tiger mom dapat meminta anak-anaknya untuk mendapatkan nilai akademik tertinggi, tanpa terlalu mempedulikan dampak psikologis atau emosional dari permintaan tersebut, tiger mom percaya bahwa ia tahu apa yang terbaik untuk anak-anak dan masa depan mereka (Chua, 2011).

Kemudian mengesampingkan keinginan anak seperti waktu luang, waktu bermain, dan kegiatan ekstrakurikuler, tiger mom percaya bahwa dia harus menghabiskan segala cara untuk mencapai tujuannya, yang mungkin termasuk mengancam, membandingkan dengan saudara kandung, memarahi, berbohong, berteriak dan menghina, membujuk dan menyuap, atau memaksa tanpa menyerah (Chua, 2011).

Sistem pengasuhan tiger parenting ini menuntut kedisiplinan yang ekstrem (Chua, 
2011). Penerapan disiplin ekstrem ini dianggap tiger mom dapat memfasilitasi pencapaian dan pengembangan akademik anak (Smetana, 2017). Orangtua yang menggunakan Tiger parenting akan membuat jadwal kegiatan anaknya untuk dipatuhi setiap hari tanpa alasan bahkan alasan sakit. Metode lain yang mewakili kekuatan orang tua dalam sistem pengasuhan tiger parenting adalah bahwa anak-anak harus menghormati otoritas. Anakanak tidak boleh bertanya dan membantah atau berbicara kembali dengan orang tua, karena orang tua percaya bahwa mereka adalah satusatunya yang tahu apa yang terbaik untuk anak-anak dan tidak ada yang bisa dinegosiasikan. Metode lain untuk mempersiapkan anak-anak menurut tiger parenting adalah memberikan yang terbaik untuk anak-anak dan mendapatkan yang terbaik dari anak-anak (Chua, 2011).

Sistem pengasuhan ini memiliki beberapa efek buruk. Disiplin yang diterapkan terlalu sulit untuk anak karena tidak ada alasan untuk kondisi buruk yang terjadi pada anak mereka. Jadwal yang dibuat juga menghancurkan masa kecil anak. Orangtua yang menerapkan Tiger parenting tidak pernah mengizinkan anaknya menghadiri acara menginap, bermain, menonton TV atau bermain game komputer, atau memilih ekstrakurikuler bahkan hobi mereka sendiri (Chua, 2011).

Orangtua ini selalu mengatur jadwal anaknya dengan banyak latihan dan tidak ada waktu untuk bermain, karena berpikir bahwa bermain hanya menyia-nyiakan waktu karena tidak berguna untuk masa depan anak-anak. Terkadang itu membuat anak-anak di bawah tekanan dan stress, salah satunya karena waktu mereka untuk latihan lebih lama daripada orang lain. Orang tua ini juga tidak terlalu peduli dengan harga diri anak (Chua, 2011).

Tiger parenting seperti yang dijelaskan oleh Chua, mendorong anak-anak untuk berjuang demi keberhasilan akademik tapi mengabaikan kesejahteraan psikologis mereka. Chua meyakini bahwa tiger parenting dapat menghasilkan tingkat prestasi akademik yang tinggi, akan tetapi hasil penelitian malah menunjukkan pencapaian pendidikan yang lebih rendah, tekanan akademik yang tinggi, dan gejala depresi pada anak dengan tiger parenting. Jika dipandang dari sudut ini maka tiger parenting tidak lebih menguntungkan daripada pengasuhan otoritatif (Kim, Shanting, Lester, \& Hou, 2017).

Beberapa studi juga memberikan bukti empiris, yang sebagian besar dilakukan di antara orang tua Asia-Amerika dan anak-anak mereka, yang menemukan bahwa tiger parenting dikaitkan dengan prestasi yang lebih rendah di sekolah (Xie \& Li, 2018). Kim et al. (2013) juga menemukan bahwa terdapat kinerja akademik yang lebih rendah pada anakanak dari tiger parenting. Tiger parenting dikaitkan dengan IPK rendah pada anak CinaAmerika (Kim et al., 2013).

Kim et al., (2015) mengungkapkan bahwa meski kelihatannya tiger parenting bermanfaat bagi anak Cina-Amerika karena berkorelasi dengan prestasi akademik dan peningkatan dari waktu ke waktu, ini memiliki efek buruk pada kesejahteraan sosial-emosional mereka (Kim, Wang, Shen, \& Hou, 2015).

Penelitian juga menunjukkan beberapa implikasi yang penting diperhatikan bagi orang tua Cina-Amerika dari anak yang berbakat secara akademis agar mengetahui bahwa meskipun tiger parenting mungkin merupakan pendekatan pengasuhan yang positif untuk penyesuaian akademik dan keterlibatan sekolah, tapi tidak dengan perkembangan lainnya seperti penyesuaian psikologis (Feld \& Shusterman, 2015).

Misalnya disiplin keras secara fisik, berteriak atau memarahi, mengekspresikan kekecewaan, dan mempermalukan, yang semuanya merupakan ciri khas pengasuhan yang otoriter, memiliki efek yang merugikan pada penyesuaian anak dalam budaya di seluruh dunia. Misalnya, orang tua yang memukul secara umum percaya bahwa itu mensosialisasikan perilaku positif. Namun, studi skala besar di A.S. dan dalam budaya berbeda-beda dalam penggunaan praktikpraktik ini menunjukkan bahwa memukul secara umum memiliki efek negatif bagi penyesuaian dan kompetensi sosial anak-anak (Gershoff et al., 2010). Selain itu Kim et al. (2013) juga menemukan bahwa pada gaya pengasuhan tiger parenting, mungkin berdampak negatif dengan perkembangan akademik dan psikososial anak secara umum. Penyesuaian emosional dan sosial mereka mungkin juga terganggu. Dengan penekanan 
diberikan pada keunggulan akademik dan kewajiban pada keluarga, anak-anak dari pengasuhan tiger parenting mungkin juga merasa sangat tertekan karena terus dituntut mendapat nilai terbaik dengan tetap memperhatikan rasa patuh (Kim et al., 2013).

Ini menunjukkan bahwa terdapat efek negatif dari tiger parenting dengan tingkatan bervariasi, seperti anak kurang bahagia, jarang bersenang-senang, sedih karena terus ditekan, merasa kurang memiliki wewenang dalam hidupnya sendiri karena segala sesuatu terus diarahkan oleh orangtua, hingga yang paling buruk yaitu gejala depresi (Irawan, 2018).

Beberapa anak dari orang tua otoriter keturunan Asia atau Tionghoa mungkin dapat menyesuaikan diri baik dalam hal perkembangan akademis dan sosial dan bahwa mereka mungkin memiliki pandangan positif tentang kepatuhan dan kontrol dari orangtua. Pandangan positif tersebut bisa dilihat dari perspektif budaya mengenai tiger parenting. Dari argumen budaya, diyakini bahwa orang Asia khususnya Cina dapat melihat elemenelemen kontrol dan ketegasan sebagai tindakan kepedulian, atau keterlibatan positif yang dilakukan oleh orang tua kepada anak-anak mereka sebagaimana diungkapkan oleh gagasan jia`o xun atau "pelatihan" dan gua $n$ atau "memerintah" (Irawan, 2018).

Jika dilihat dari sudut positif maka sifat mengendalikan dan menuntut pengasuhan tiger parenting dapat dipahami sebagai bentuk pengasuhan dengan niat baik dari orang tua untuk anak-anak mereka, dan oleh karena itu kepatuhan pada kontrol dan tuntutan adalah hal baik yang diharapkan sebagai anak yang baik (Irawan, 2018).

Ketika anak-anak menggunakan perspektif seperti itu, maka kontrol dan permintaan orangtua dipandang sebagai karakteristik biasa atau bahkan yang diharapkan dari orangtua yang baik dan bertanggung jawab. Ketaatan dalam keluarga Cina merupakan bentuk kebaikan anak setiap hari dan karenanya dipandang sebagai hal yang baik. Jadi seorang anak Cina mungkin melihat kepatuhan sebagai sesuatu yang harus dia capai dan tampilkan sebagai anak yang baik. Jika dengan pandangan positif seperti itu, pengasuhan tiger parenting kemudian dapat memberikan hasil positif dalam perkembangan anak-anak (Irawan, 2018).

Akan tetapi faktanya, anak-anak yang memiliki latar belakang supportive parenting secara konsisten menunjukkan penyesuaian keseluruhan yang lebih baik bila dibandingkan dengan anak-anak yang memiliki latar belakang tiger parenting (Kim et al., 2017).

Tiger parenting tidak dapat dianggap sebagai gaya pengasuhan Cina yang biasa digunakan oleh kebanyakan orangtua di Cina atau bahkan dianggap sebagai gaya pengasuhan di Cina secara spesifik, karena studi menunjukkan bahwa tiger parenting bukanlah gaya pengasuhan yang paling umum di kalangan orang Cina-Amerika. Terlepas dari persepsi populer bahwa tiger parenting berkontribusi terhadap kesuksesan masa depan, temuan ini menunjukkan bahwa sebenarnya supportive parenting lebih mendorong hasil yang optimal pada anak-anak Cina-Amerika (Kim et al., 2017).

Secara khusus, Kim et al. (2013) menemukan bahwa tiger parenting bukanlah profil yang umum pada orangtua CinaAmerika (Xie \& Li, 2018). Data penelitian juga telah menemukan bahwa orang tua Cina kontemporer cenderung lebih berwibawa, terutama di perkotaan Cina. Temuan penelitian ini menunjukkan bahwa gaya pengasuhan Cina kontemporer misalnya di Shenzhen sebagian besar berwibawa atau bersifat melatih anak, dengan data tujuh puluh dua ibu (84\%) dan tujuh puluh dua ayah (84\%) mendapat skor tertinggi dalam pengasuhan otoritatif; tiga belas ibu $(15 \%)$ dan tiga belas ayah $(15 \%)$ mendapat nilai tertinggi dalam training, sedangkan hanya satu ibu (1\%) dan satu ayah (1\%) yang mendapat skor tertinggi dalam pengasuhan yang otoriter (Xie \& Li, 2019).

\section{Dampak Tiger Parenting bagi Perkembangan Emosi}

\section{Dampak Negatif}

Sebagaimana telah disinggung mengenai dampak yang ditimbulkan dari penerapan tiger parenting bagi anak khususnya perkembangan emosinya maka ada beberapa hal yang bisa diketahui yaitu kurang bahagia karena tidak mendapat ijin untuk bermain dengan leluasa baik itu bermain dengan teman sebaya maupun 
sekedar bermain dengan game atau menonton $\mathrm{TV}$, dengan waktu bermain yang leluasa juga anak menjadi jarang memiliki waktu untuk bersenang-senang.

Bagi anak yang tidak kuat mendapat tekanan dari tiger mom bisa saja perkembangan emosi negatifnya lebih baik dari emosi positif dan ini jelas bukan hal yang baik mengingat tidak ada keseimbangan dari keduanya. Perkembangan emosi negatif yang berkembang lebih baik pada penerapan tiger parenting ini misalnya marah, sedih, dan takut. Perkembangan emosi negatif ini bisa muncul disebabkan karena tuntutan yang diberikan oleh orangtua begitu besar dan kurang diberikan kesempatan untuk mengutarakan keinginannya.

Waktu bermain dan bersenang-senang yang terbatas baik sendiri maupun dengan teman sebayanya juga bisa menjadi penyebab perkembangan emosi positif anak menjadi kurang baik, hal ini bisa terjadi karena anak kurang terbiasa mengekspresikan rasa senangnya dengan bermain secara leluasa.

Lebih lanjut, anak juga bisa merasa kurang memiliki wewenang terhadap dirinya sendiri karena berbagai hal telah diatur dan ditentukan oleh orangtuanya. Hal paling buruk yang bisa terjadi adalah munculnya rasa depresi dari anak karena orang tua dengan tiger parenting berusaha menekan anak dengan segala cara tanpa memperhatikan dampak psikologis anak.

\section{Dampak Positif}

Beberapa dampak positif yang dapat diambil dari penerapan tiger parenting yaitu orangtua yang sangat bertanggungjawab terhadap masa depan anaknya karena orangtua ini akan melakukan hal-hal yang dapat membuat masa depan anaknya menjadi baik, mengajari anak untuk lebih patuh dan menjadi disiplin, mengajari anak unuk berusaha terus tanpa kenal menyerah khususnya untuk mencapai hasil akademik yang memuaskan.

\begin{tabular}{ccc}
\hline No. & Aspek Penilaian & Skor \\
\hline 1 & & \\
\hline 2 & & \\
\hline
\end{tabular}

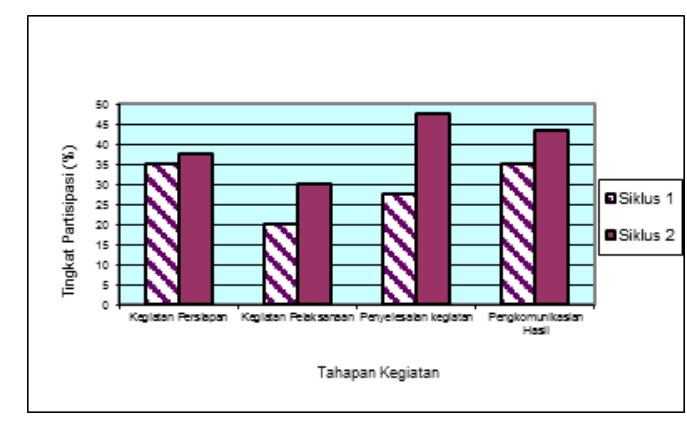

Figure 1. <Title of Figure>

\section{CONCLUSION}

Dampak positif dari tiger parenting ini seperti orangtua yang sangat bertanggungjawab terhadap masa depan anaknya, mengajari anak untuk lebih patuh dan menjadi disiplin, mengajari anak unuk berusaha terus tanpa kenal menyerah khususnya untuk mencapai hasil akademik yang memuaskan.

Meski untuk perkembangan emosi secara khusus lebih banyak dampak negatifnya seperti anak kurang bahagia, jarang bersenang-senang, sedih karena terus ditekan, merasa kurang memiliki wewenang dalam hidupnya sendiri karena segala sesuatu terus diarahkan oleh orangtua, hingga yang paling buruk yaitu gejala depresi.

Menjadi hangat, menggunakan alasan dan penjelasan ketika mendisiplinkan anak-anak, memungkinkan anak-anak menjadi mandiri pada saat yang tepat, dan memantau keberadaan dan kegiatan anak-anak merupakan strategi pengasuhan yang baik. Orang tua juga harus memastikan bahwa mereka meminimalkan berteriak atau meneriaki anak-anak, mempermalukan anak-anak seperti membandingkan mereka dengan anak-anak lain, mengharapkan kepatuhan yang tidak dipertanyakan dari anak-anak mereka, dan menyalahkan anakanak mereka atau mengemukakan kesalahan masa lalu. Karena bagaimanapun juga perkembangan emosional anak perlu diperhatikan dengan baik agar anak dapat tumbuh dengan seimbang. 


\section{REFERENSI}

Ahmadi, A., \& Uhbiyati, N. (2001). Ilmu Pendidikan. Jakarta: Rineka Cipta.

Ali, M., \& Asrori, M. (2006). Psikologi Remaja: Perkembangan Peserta Didik. Jakarta: Bumi Aksara.

Chang, T.-F., \& Qin, D. B. (2017). Training and Adolescent Adjustment among Academically Gifted European and Chinese American Students. Sociology and Anthropology, 5(9), 732-744. https://doi.org/10.13189/sa.2017.050905

Chua, A. (2011). Battle Hymn Tiger Mom. 2011: The Penguin Press.

Dagun, M. (2002). Psikologi Keluarga. Jakarta: Rineka Cipta.

Desmita. (2005). Psikologi Perkembangan. Bandung: Remaja Rosdakarya.

Feld, L. D., \& Shusterman, A. (2015). Into the pressure cooker: Student stress in college preparatory high schools. Journal of Adolescence, 41(March 2015), 31-42. https://doi.org/10.1016/j.adolescence.201 5.02 .003

Gershoff, E. T., Grogan-Kaylor, A., Lansford, J. E., Chang, L., Zelli, A., DeaterDeckard, K., \& Dodge, K. A. (2010). Parent Discipline Practices in an International Sample: Associations With Child Behaviors and Moderation by Perceived Normativeness. Child Development, $\quad 81(2), \quad 487-502$. https://doi.org/10.1038/jid.2014.371

Irawan, S. (2018). Tiger mother and her cubs on a stage: 'Tiger ' parenting style and its effects in Listen to Me. 2639(April 2017), $33-41$ https://doi.org/10.9744/kata.20.1.33-41

Kim, S. Y., Shanting, C., Lester, S., \& Hou, Y. (2017). Stability and Change in Parenting and Adjustment Profiles Across Early, Middle, and Late Adolescence in Chinese American Families. In Asian American parenting: Family process and intervention (pp. 69 88). https://doi.org/10.1007/978-3-31963136-3

Kim, S. Y., Wang, Y., Shen, Y., \& Hou, Y. (2013). Does "Tiger Parenting" Exist? Parenting Profiles of Chinese Americans and Adolescent Developmental Outcomes. Asian American Journal of
Psychology, 4(1), 7-18. https://doi.org/10.1037/a0013262.Open

Kim, S. Y., Wang, Y., Shen, Y., \& Hou, Y. (2015). Stability and Change in Adjustment Profiles Among Chinese American Adolescents: The Role of Parenting. Journal of Youth and Adolescence, 44(9), 1735-1751. https://doi.org/10.1007/s10964-0150303-3

Latifa, U. (2017). Aspek Perkembangan pada Anak Sekolah Dasar: Masalah dan Perkembangannya. Journal of Multidisciplinary Studies, 1(2), 185-196.

Latipun, M. N. (2005). Kesehatan Mental: Konsep dan Penerapan. Malang: UMM Press.

Lestari, S. (2012). Psikologi Keluarga: Penanaman Nilai dan Penanganan Konflik dalam Keluarga. Jakarta: Kencana.

Liew, J. (2010). Parenting and Emotion Regulation in the Adaptive and Academic Competencies of Chinese American Youth. (May), 10-12.

Minkyeong, S., \& Joel, W. Y. (2013). Beyond the Tiger Mom: Asian American Parenting and Parent-Child Relationships (B. PETER \& P. STELIOS, eds.). https://doi.org/10.4018/978-1-52254168-4.ch005

Muadz, \& Dkk. (2010). Penyiapan Kehidupan Berkeluarga Bagi Remaja ditinjau dari aspek 8 fungsi keluarga, kesehatan, ekonomi, peikologi, pendidikan, agama dan sosial. Jakarta: BkkbN.

Mulyani, N. (2013). Perkembangan Emosi dan Sosial Pada Anak Usia Dini. INSANIA : Jurnal Pemikiran Alternatif Kependidikan, 18(3), 423-438. https://doi.org/10.24090/insania.v18i3.14 70

Setyowati, Y. (2013). Pola Komunikasi Keluarga dan Perkembangan Emosi Anak (Studi Kasus Penerapan Pola Komunikasi Keluarga dan Pengaruhnya terhadap Perkembangan Emosi Anak pada Keluarga Jawa). Jurnal ILMU KOMUNIKASI, 2(1), 67-78. https://doi.org/10.24002/jik.v2i1.253

Shaleh, M. (2016). Pengaruh Motivasi, Faktor 
Keluarga, Lingkungan Kampus Dan Aktif Berorganisasi Terhadap Prestasi Akademik. Phenomenon: Jurnal Pendidikan MIPA, 4(2), 109. https://doi.org/10.21580/phen.2014.4.2.1 22

Smetana, J. G. (2017). Current research on parenting styles, dimensions, and beliefs. Current Opinion in Psychology, 15, 1925.

https://doi.org/10.1016/j.copsyc.2017.02. 012

Soetjiningsih. (1995). Tumbuh Kembang Anak. Jakarta: Buku Kedokteran EGC.

Suriadi, \& Yuliani, R. (2006). Asuhan Keperawatan Pada Anak Edisi 2. Jakarta: Sagung Setia.

Xie, S., \& Li, H. (2018). Does tiger parenting work in contemporary China? Exploring the relationships between parenting profiles and preschoolers' school readiness in a Chinese context. Early Child Development and Care, 188(12), 1824-1840.

https://doi.org/10.1080/03004430.2018.1 521806

Xie, S., \& Li, H. (2019). 'Tiger mom, panda dad': a study of contemporary Chinese parenting profiles. Early Child Development and Care, 189(2), 284300.

https://doi.org/10.1080/03004430.2017.1 318870

Yusuf, S. (2008). Psikologi Perkembangan Anak dan Remaja. Bandung: Remaja Rosdakarya. 